\title{
Sterilization of the Retarded: A Problem or a Solution?
}

\author{
Charles W. Murdock*
}

That sterilization today is a subject of considerable interest can hardly be denied. Planned Parenthood has its pamphlet on the subject, ${ }^{1}$ and even the Wall Street Journal finds the topic of sufficient interest to intermingle with the financial news. ${ }^{2}$ While ethical ${ }^{3}$ and psychological $^{4}$ assessments of sterilization may differ, few would deny that the operation should be performed only upon those who knowingly consent to it. ${ }^{5}$

Professor of Law, Notre Dame University. B.S.C.H.E., Illinois Institute of Technology, 1956; J.D., Loyola University, Chicago, 1963.

1. Medical Dep'T, Planned Parenthood-World Populatton, Voluntary Steriltzation for Men and Women: The SURESt WaY to Avoid UNwanted PREGNANCY (1970).

The Association for Voluntary Sterilization announced that for the period from 1970 to 1972 vasectomies were performed at an annual rate of about 750,000 per year. Other sources indicate that the rate may be closer to half that reported by the Association. See Washington Post, July 5, 1973, $\$$ C, at 1, col. 6 (also indicating that more than 3 inillion Americans of child-bearing age have been sterilized and that the figure is increasing by about a million annually).

2. Wall Street Journal, Apr. 7, 1972, at 9, col. 2 (Pacific Coast ed.); Wall Street Journal, Sept. 26, 1972, at 1, col. 5 (Pacific Coast ed.). Even the Internal Revenue Service got into the act, ruling that the cost of a voluntary sterilization is deductible as a medical expense. Rev. Rul. 73-201, 1973-1 CuM. Bull. 140.

3. Even in the Roman Catholic sphere there is disagreement. While the American Bishops in 1971 set forth the general premise that sterilization is a disapproved means of contraception, U.S. Catholic Conference, Ethical and Religious Directives for Catholic Health Facilities (available from the Department of Health Affairs-U.S. Cat. Conf., 1312 Massachusetts Avenue, N.W., Washington, D.C. 20005), Catholic theologians have criticized such a position as being too arbitrary, see WASSMER, ChristIAN ETHICS FOR TODAY 177-82 (1969). For a current discussion of this area that reflects the varying points of view, see Curran, Sterilization: Roman Catholic Theory and Practice, 40 LINACRE QUART. 97 (1973); Eugenic STERILIzATION 48-49, 103-04 (J. Robitscher ed. 1973).

4. Some professionals in the inental health and related fields believe "too inuch weight has been placed on the possible adverse effects of sterilization and too little on the benefits." Laidlaw \& Bass, Voluntary Sterilization As it Relates to Mental Health, 120 AM. J. Psychiatry 1176, 1178 (1964). Undoubtedly sterilization is gaining greater acceptance today. See notes 1-3 supra. However, there are "many varied reactions to sterilization, ranging from a feeling of personal guilt to aggression against the surgeon, from a sense of being defeminized to a sense of relief." Barnes \& Zuspan, Patient Reaction to Puerperal Surgical Sterilization, 75 AM. J. OBST. \& GYNEC. 65, 69 (1958). See also Wolf, Legal and Psychiatric Aspects of Voluntary Sterilization, 3 J. FAM. L. 103, 109-118 (1963).

5. See Clark, Religion, Morality, and Abortion: A Constitutional Appraisal, 
But unfortunately sterilization is not limited only to those who freely submit to it. In 1973, news of the sterilization of the two Relf girls in Alabama made headlines across the country when their father filed a lawsuit against various welfare agencies and officials, alleging that his daughters had been sterilized without his consent. ${ }^{\circ}$ The Relf case contains a further complication: one of the girls was retarded. ${ }^{\top}$

Little known is the faot that many retarded children are "voluntarily" sterilized at the request of their parents. Although statistics are scarce on the prevalence of such sterilizations, they probably lave become more common with the growing acceptance of the principle of normalization - the recognition of the right, among others, of the retarded person to live in the community instead of being hidden at home or confined to an institution. ${ }^{8}$ As retarded persons imcreas-

2 LOYOLA L.A. L. REv. 1, 8 (1969).

At one time, voluntary sterilization was prohibited in Connecticut, Kansas, and Utah. See Forbes, Voluntary Sterilization of Women As a Right, 18 DE PAUL L. Rev. 560, 561 (1969); Holman, Medicolegal Aspects of Sterilization, Artificial Insemination, and Abortion, 156 J.A.M.A. 1309, 1310 (1954); Tierney, Voluntary Sterilization-A Necessary Alternative?, 4 FAM. L. Q. 373, 378 (1970). In these three states, however, statutory or case law developments now recognize the validity of voluntary sterilization. ConN. Gen. Stat. ANN. \& 19-66b (Supp. 1973); KAN. Stat. ANN. $\S \S 65-446$ to -447 (1972); Parker v. Rampton, 28 Utah 2d 36, 497 P.2d 848 (1972).

6. See Washington Post, June $28,1973, \S$ A, at 29 , col. 3. One girl was 14 and the other 12. The girls' father was not contacted but the mother "consented" by signing her " $X$," allegedly thinking she was merely signifying her approval to the birth control shots the girls had been receiving. The story soon moved to the front pages. E.g., Washington Post, July 3, 1973, § A, at 1, col. 6 (citing an OEO official's estimate that eleven girls and a total of 82 persons had been sterilized by the Montgomery birth control clinic and the state of Alabama); Washington Post, July 4, 1973, \& A, at 1, col. 5; Washington Post, July 6, 1973, $\$$ A, at 1, col. 3; Washington Post, July 8, 1973, § A, at 1, col. 5. See also Washington Post, July 8, 1973, § A, at 1, col. 7; Raspberry, 'Agonizing Questions' on Sterilization, Washington Post, July 13, 1973, § A, at 29, col. 4; Will, Sterilization and 'Population Improvement,' Washington Post, July 23, 1973, § A, at 22, col. 4; Raspberry, Reader Responses to Sterilization Issue, Washington Post, July 25, 1973, \$ A, at 17, col. 5 .

While the initial Relf suit was ultimately dismissed, a second suit was filed in which the HEW authorization of funds for sterilization of legal or judicial incompetents was held to exceed the agency's legislative authority, and suggesting such a practice would be unconstitutional. Relf v. Weinberger, 42 U.S.L.W. 2493 (D.D.C. Mar. 15, 1974).

7. Washington Post, July $6,1973, \S \mathrm{A}$, at 1 , col. 3 .

8. Normalization has been described as follows:

[T] he normalization principle means making available to the mentally retarded patterns and conditions of everyday life which are as close as possible to the nonns and patterns of the mainstream of society.

This principle should be applied to all the retarded, regardless whether mildly or profoundly retarded, or whether living in the homes of their parents or in group bomes with other retarded. The principle is useful in every society, with all age groups, and adaptable to social changes and individual developments. 
ingly coine to live in a normal heterosexual environment, the likelihood of parenthood also increases. Anxious parents, thinking that they face a choice between institutionalizing their retarded offspring or exposing them to the risk of parenthood, look upon sterilization as a solution to their probleins. ${ }^{9}$ Since sexual relationships are apparently inevitable, and retardation supposedly irreversible, sterilization seems the perfect answer. Often ignored, however, is the severe, even trauinatic impact of sterilization on retarded persons. Witness one retarded woman's reaction to being sterilized:

When they done that to me I cried. I'm a Catholic and that's wrong. We're brought in this world to bear children. I see all my friends and they have children. I love kids. Sometimes now when I baby sit, I hold the baby up to myself and I think to myself, "Why was I ever sterilized?"10

Nirje, The Normalization Principle and Its Human Management Implications, in Changing Patterns in Residential Services for the Mentally Retarded, 179, 181 (R. Kugel \& W. Wolfensberger, eds. 1969).

The most complete elaboration of the principle is found in W. WOLFENSBERGER, The Principle of Normaidzation In Human Services (1972). See also R.

Perske, New Directions for Parents of Persons Who are Retarded (1973).

A major thrust of the norinalization movement is to move retarded persons out of warehousing institutions and into their communities. SEXUAI RIGHTS AND RESPONSIbiLities of tHe Mentally Retarded-Proceedings of the Conference of tHe American Association on Mental Deficiency, Region IX 16 (M. Bass ed. 1973) (available from M.S. Bass, 216 Glenn Rd., Ardmore, Pa. 19003) [hereinafter cited as Sexual Rights]. The principle has been given a legislative impetus. For example, Indiana has enacted the following:

It is the intent of the state of Indiana to develop through leasing a variety of needed community residential facilities for the mentally retarded. These facilities will relate to the full range of community programs and resources. IND. StAT. ANN. \& 16-16-2A-1 (1973). California also has enacted a comprehensive legislative program for establishing community services and has, in fact, begun to implement the program. See CaL. Hearth \& SAF. Code $\$ 38100-09$ (West 1973). Kay, Farnham, Karren, Knakal \& Diamond, Legal Planning for the Mentally Retarded: The California Experience, 60 CaLIF. L. REv. 438 (1972).

The program for de-emphasizing large state institutions and emphasizing the community facilities has not always been greeted with enthusiasm. See Endicott, Retarded Face Uncertain Fate as State Hospitals Cut Back, Los Angeles Times, Apr. 2, 1973, $\S C(I I)$ at 1, col. 1; Washington Post, Aug. 3, 1973, § C, at 1, col. 8. An editorial in the Washington Post stated;

The second part of this goal [returning to the community] may be more difficult to attain than the first [reducing the incidence of retardation], because it challenges not only scientists, educators, social workers, and government officials. It challenges all of us. It challenges not just our compassion for the mentally retarded, but our acceptance of them-as people. People do not live in institutions or "facilities." They live in homes.

Washington Post, Aug. 4, 1973, § A, at 14, col. 1 .

9. For similar reasons the state may condition release of institutionalized retarded persons upon sterilization. See The MeNtaley Disabled and THE LAW 22022, table 6.1 (rev. ed., S. Brakel \& R. Rock eds. 1971).

10. Sabagh \& Edgerton, Sterilized Mental Defectives Look at Eugenic Sterilization, 9 EUGENICS Q. 213, 220 (1962). 
This Article explores the problems inherent in sterilization of the retarded. In the main, it analyzes the constitutionality of statutes that authorize involuntary sterilization of the retarded. Retardation, however, also raises problems with respect to voluntary sterilization. The questions of consent and who can give it are therefore also briefly examined.

\section{HISTORICAL BACKGROUND}

From the time of Plato, social theorists have advocated selective breeding in order to improve the human race. ${ }^{11}$ Until the end of the nineteenth century, however, sterilization could not be used for eugenic purposes because it could only be accomplished through castration, a means that was medically dangerous and widely regarded as morally unacceptable. The advent of the twentieth century brought medical procedures which were less hazardous and which lacked the moral opprobrium attached to castration. ${ }^{12}$ In this country statutes permitting involuntary sterilization date from the development of these procedures. $^{13}$

Such statutes have not been spared constitutional attack, either on due process or on equal protection grounds. ${ }^{14}$ But while the procedural adequacy of involuntary sterilization statutes has remained open to question, ${ }^{15}$ objections on substantive due process and equal protection grounds were seemingly put to rest in 1927 by Buck $v$. Bell. ${ }^{16}$ The issue before the Supreme Court in Buck was the validity of a Virginia statute authorizing the sterilization of patients in state institutions who were afflicted with hereditary forms of mental illness or mental retardation. The statute was premised on the assumption that the state was supporting in institutions "many defective persons who if . . . discharged would become a menace but if incapable of procreating might be discharged with safety and become self-supporting with benefit to themselves and to society."17

Justice Holmes, writing for the Court, found no denial of equal protection. The statutory classification, which allowed sterilization

11. See Vukowich, The Dawning of the Brave New World-Legal, Ethical, and Social Issues of Eugenics, 1971 U. IIL. L. FORUM 189.

12. The Mentally Disabled and tHe LAW 207-08 (rev, ed., S. Brakel \& R. Rock eds. 1971). Chapter Six of this work, entitled "Eugenic Sterilization," provides an excellent overview of the legal development in eugenic sterilization. Id. at 207-19. The tables following the chapter analyze statutory provisions of various states.

13. Id. at 207-08.

14. Id. at $212-16$.

15. Id. at 215-16.

16. 274 U.S. 200 (1927).

17. Id. at 205-06. 
only of those within institutions, furthered the stated purpose of the legislation, the release of those who otherwise would be detained. The evil was detention at public expense; the solution was discharge once harmless. Therefore, limiting sterilization to the institutionalized was fully rational. ${ }^{18}$

The Court also found no denial of substantive due process. it accepted the trial court's finding that "Carrie Buck is the probable potential parent of socially inadequate offspring." "18 Analogizing sterilization to compulsory vaccination, the Court held that the means chosen were reasonably related to a permissible state purpose, preventing society from being "swamped with incompetence." ${ }^{20}$ In the infamous closing words of Justice Holmes: "Three generations of imbeciles are enough." 21 While the current soundness of the constitutional analysis employed by Justice Holmes will be questioned below, at this point it should be observed that the basic fact upon which his conclusion was based was in error: Carrie Buck's baby was apparently not an imbecile, but rather a normal child. ${ }^{22}$

II

\section{The Current Legal Perspective}

Although Buck has never been explicitly overruled, the Count's reasoning would almost certainly be inadequate today. Its holding rests on a standard of review, rational basis, which affords challenged legislation an almost insurmountable presumption of validity. At one time nearly the exclusive test in equal protection cases, rational basis is today only one of several standards used by the Count in deciding founteenth amendinent issues. Since 1942 equal protection analysis has included a "strict scrutiny" test ${ }^{23}$ reserved for classifications ấ-

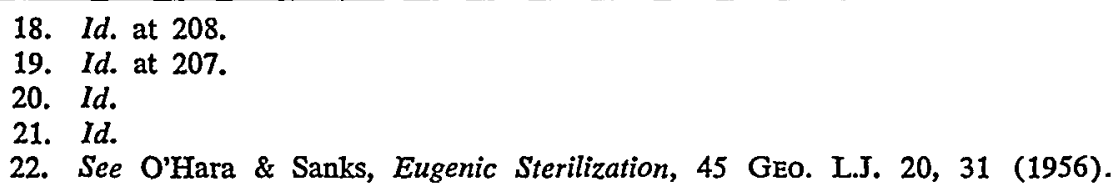
Some doubt as to the facts accepted by the Supreme Court in the Buck case was raised by subsequent investigation by Dr. J. E. Coogan, a Detroit sociologist. Coogan, Eugenical Sterilization Holds a Jubilee, THE Catholic WoRLd, April 1953, at 45. Carrie Buck was supposed to have been the 18-year-old imbecile daughter of an imbecile mother, and herself the mother of an imbecile daughter. Carrie's mother, the first generation imbecile, was a moron (mildly retarded) and not an imbecile (moderately retarded). Carrie Buck was given an intelligence test and also found to be a moron. Her daughter, supposedly the third generation inbecile, was only one month old at the time she was appraised as mentally defective by a Red Cross nurse. Dr. Coozan found that the daughter, who died in the summer of 1932 of measles after having coinpleted the second grade, was reportedly very bright.

For the significance of the characterization of a person as mildly or moderately retarded, see text accompanying notes 65-66 infra.

23. E.g., Loving v. Virginia, 388 U.S. 1, 11 (1967) ("the most rigid scrutiny"). 
fecting "fundamental interests"24 or involving "suspect criteria." Additionally, the Court has most recently employed a "means-focused" review or balancing approach in a few cases. ${ }^{26}$

Due process analysis today has similar diversity. Where legislation touches upon fundamental interests the statute must not be unnecessarily broad, ${ }^{27}$ nor effect an irrebuttable presumption, ${ }^{28}$ and must use the least burdensome means available. ${ }^{20}$ As will be seen, the right to procreate is among the fundamental interests that trigger nore active review under inodern interpretations of the equal protection and due process clauses. In short, the rational basis reasoning of Buck, sufficient in 1926, would be anachronistic today. ${ }^{30}$

Skinner v. Oklahoma ex rel. Williamson ${ }^{31}$ is the landmark case establishing procreation as a fundamental interest. The Court there held that legislation authorizing involuntary sterilization of larcenists but not embezzlers-a nearly indistinguishable class of criminalsviolated the equal protection clause. In justifying its nondeferential treatment of the statute before it, the Court noted: "We are dealing here with legislation which involves one of the basic civil rights of inan. Marriage and procreation are fundamental to the very existence and survival of the race." 32

Subsequent cases have contimued to apply the "strict scrutiny" standard of review to statutes regulating the individual's decision whether or not to have children. In Eisenstadt v. Baird, ${ }^{33}$ for instance, the Court invalidated a statute that permitted distribution of

24. E.g., Harper v. Virginia Bd. of Elections, 383 U.S. 663 (1966) (voting); Shapiro v. Thompson, 394 U.S. 618 (1969) (travel); Griswold v. Connecticut, 381 U.S. 479 (1965) (privacy); Roe v. Wade, 410 U.S. 113 (1973) (abortion).

25. E.g., McLaughlin v. Florida, 379 U.S. 184 (1964) (race); Graham v. Richardson, 403 U.S. 365 (1971) (alienage); Levy v. Louisiana, 391 U.S. 68 (1968) (legitimacy, by implication); Frontiero v. Richardson, 411 U.S. 677 (1973) (sex, held a suspect classification by four members of the Court).

26. Gunther, The Supreme Court, 1971 Term-Foreword: In Search of Evolving Doctrine on a Changing Court: A Model for a Newer Equal Protection, 86 HARv. L. REv. 1, 20 (1972); see, e.g., Eisenstadt v. Baird, 405 U.S. 438 (1972); Dandridgo v. Williams, 397 U.S. 471, 508 (1970) (Marshall, J., dissenting). See also Weber v. Aetna Cas. \& Sur. Co., 406 U.S. 164 (1972).

27. E.g., Griswold v. Connecticut, 381 U.S. 479, 485 (1965).

28. E.g., Stanley v. Illinois, 405 U.S. 645 (1972); Cleveland Bd. of Education v. LaFleur, 94 S. Ct. 791 (1974).

29. See Shelton v. Tucker, 364 U.S. 479 (1960).

30. Even under the mimimal scrutiny "rational basis" standard, as recently interpreted by the Court, Buck might be wrong. The classification might be found "irrationally underinclusive" for the purpose of ending imbecility. Cf. Cleveland Bd. of Education v. LaFleur, 94 S. Ct. 791, 802-04 (1974) (Powell, J., concurring).

31. 316 U.S. 535 (1942).

32. Id. at 541 .

33. 405 U.S. 438 (1972). 
certain contraceptives to married but not unmarried persons. ${ }^{34}$ While Eisenstadt used equal protection reasoning, ${ }^{35}$ the individual's interest in procreation has triggered active review through due process analysis as well. Griswold v. Connecticut, ${ }^{36}$ for example, held that the marriage relationship falls within a constitutionally. protected zone of privacy. The Court found that a statute prohibiting the use of contraceptives violated the due process clause to the extent it denied this right to privacy. And most recently Roe v. Wade ${ }^{37}$ held that the decision to have an abortion lies within the constitutionally protected right to privacy recognized in Griswold. A state may not abridge or deny the right to an abortion absent a "compelling state interest," a standard of review far more rigorous than the rational basis test of Buck v. Bell. ${ }^{38}$

Today, statutes that affect family life and procreation, as sterilization does in such a heavy-handed way, demand from the state far more justification than was thought necessary in 1926. This higher degree of justification dcmands more than that the state interest served by the statute be legitimate. As the Court poimted out in Griswold," the state interest may not be achieved by "means which sweep unnecessarily broadly and thereby invade the area of protected freedoms." ${ }^{40}$ Where less drastic ${ }^{41}$ or less restriative alternatives ${ }^{42}$ are available, they must be chosen. Nor is it enough that the statute serve administrative convemience; as the Court stated in Stanley v. Illinois, ${ }^{43}$ "the Constitution recognizes higher values than speed and efficiency." 44

In summary, when a fundamental interest such as procreation is involved, the justification required of the state under equal protection or due process analysis is essentially the same: It must demonstrate that the statute serves a state interest of sufficient importance

34. Id. at $441,454-55$.

35. Id. at $446-55$.

36. 381 U.S. 479 (1965).

37. 410 U.S. 113 (1973).

38. 274 U.S. 200 (1927).

39. Griswold v. Connecticut, 381 U.S. 479 (1965).

40. Id. at 485 .

41. In Shelton v. Tucker, 364 U.S. 479 (1960), the Supreme Court stated: "[E]ven though the governmental purpose be legimate and substantial, that purpose cannot be pursued by means that broadly stifle fundamental personal liberties when the end can be more narrowly achieved. The breadth of legislative abridgment must be viewed in the light of less drastic means for achieving the same basic purpose." Id. at 488 .

42. For an excellent discussion of the doctrine of the less drastic means or least restrictive alternative, see Chambers, Alternatives to Civil Committment of the Mentally Ill: Practical Guides and Constitutional Imperatives, 70 MrCH. L. REv. 1107 (1972).

43. 405 U.S. 645 (1972).

44. Id. at 656 . 
to subordinate the personal liberty involved. Not surprisingly states have found this burden difficult if not impossible to carry. ${ }^{45}$

Two legitimate state interests might be served by involuntary sterilization of the retarded. The first is eugenic: the interest in avoiding another generation of retarded persons and, inore generally, in improving the gene pool of the population. The second is the state's interest in providing children with fit and capable parents. Sterilization of the retarded serves this latter goal, or so it might be argued, because retarded persons are presumptively unfit to raise children. There is also a third state interest derived from these first two: the interest in saving money that would otherwise be spent on caring for children who were either retarded themselves or who could not be raised by their retarded parents. But the state interest in saving money has never justified demal of fundamental individual interests. ${ }^{40}$ For this reason only the state interests in eugenics and in fitness for parenthood need be separately considered. ${ }^{47}$

\section{III}

\section{EUGENICS AS A BASIS FOR STERILIZATION}

Like the statute considered in Buck v. Bell, ${ }^{48}$ most statutes authorizing involuntary sterilization of the retarded are premised upon a eugenic purpose: preventing the birth of children who will inherit genetic defects. Not all retardation, however, is genetically based. In fact, three different bases are discernible: purely genetic, both genetic and environmental, and purely environmental.

Two examples of the first type are Downs syndrome and TaySachs disease. Downs syndrome is characterized by an extra chroinosoine and is transmitted, if at all, ${ }^{49}$ by a dominant gene. Tay-Sachs disease, on the other hand, is transmitted by a recessive gene. Despite this difference, a sterilization program designed to reduce the incidence of either form of retardation would require sterilizing many more normal than retarded persons. In cases of Downs syndrome

45. Only once, in Korematsu v. United States, 323 U.S. 214 (1944), has the Court found a compelling state interest.

46. E.g., Stanley v. Illinois, 405 U.S. 645,656 (1972).

47. Both interests involve a concern for unborn children, yet both seek to serve this concern, somewhat paradoxically, by preventing birth. Despite the possible contradiction, the interests will be accepted as legitimate and reviewed only as to their being compelling.

48. 274 U.S. 200 (1927).

49. The syndrome is not ordinarily inherited because afflicted iudividuals generally do not reproduce. In civilized societies they are institutionalized and isolated from sexual contacts. In the state of nature their severe disability militates against survival to adolescence and conceivably reduces fertility of survivors. 
the defective gene is rarely inherited by the parents; it is usually a mutation of the mother's genes associated with advanoing age. The mutation itself does not produce retardation in the mother but only in a child; ${ }^{50}$ that is, the carrier usually is not retarded and therefore not identifiable on that basis. With Tay-Sachs disease, on the other hand, the affected child usually dies before puberty. Preventing this form of retardation, therefore, would require sterilizing persons who carry the recessive gene but remain unafflicted by the disability. ${ }^{51}$

In other cases the defect, though genetic, requires the influence of environmental factors to produce retardation. For example, galactosemia will cause retardation only in children, who are fed milk, since the hereditary defect does not itself cause retardation but only prevents metabolism of milk sugar. ${ }^{52}$ Similarly, diet is a factor in causing retardation from phenylketonuria (PKU), ${ }^{53}$ and a controlled diet may lessen or avert the retardation which otherwise accompanies this genetic condition. Where retardation results from these and similar combinations of genetic and environmental factors, identifying the relevant environmental factors and controlling them is all that is necessary to avoid retardation.

Finally, retardation may result solely from environmental factors. Trauma can cause brain injury and retardation. ${ }^{54}$ Moreover, some retardation formerly thought to be hereditary is now known to result from an impoverished intellectual or emotional environment that deprives children of the stimulation necessary for mental growth and developinent. ${ }^{55}$

These non-genetic causes of retardation reveal the obvious weaknesses of eugenic justification for sterilizing the retarded. Sterilization is inapposite where the retardation results solely from environ-

50. See generally H. Robinson \& N. Robinson, THE MENTALLY RETARded Cimld 103-06 (1965). The risk to the offspring is correlative with the mother's age: 1 in 1,000 or better in inothers under the age of 35 , but increasing rapidly to approximately 1 in 38 for a mother who is 45 . Id. at 97 .

51. See notes 56-57 and accompanying text infra.

52. H. Robinson \& N. RobnNson, supra note 50, at 64, 109.

53. Id. at 109-11.

54. Id. at 158.

55. See Garbor, The Milwaukee Project: An Experiment on the Prevention of Cultural-Familial Mental Retardation-Intervention at Birth, in SEXUAL RighTs, supra note 8, at 70. Garber described the "Milwaukee Project," in which children of low I.Q. mothers were studied under controlled circumstances. The children in one group were provided with an enriched environment to facilitate achievement motivation, problem-solving skills, and language development for the purpose of determining whether so-called cultural-familial retardation was genetic in nature or caused by the generally impoverished environment of the ghetto, or possibly attributable to the impoverished stimulation provided by the home, particularly the parents. The author tentatively concluded that the primary cause is the home environment and that early intervention can avoid the syndrom of cultural-famihal retardation. Id. at 82-86. 
mental factors; moreover, retardation dependent upon both genetic and environmental factors can, at least in some cases, be prevented by means less onerous than sterilization.

But even retardation resulting solely from inheritance of defective genes cannot be greatly reduced by sterilizing only the retarded, for eighty to ninety percent of retarded offspring are born to normal parents. ${ }^{56}$ Although this figure reflects the effects of mutation and environmental factors, it also suggests the significance of recessive genes in causing inheritable retardation. A recessive gene, such as is involved in Tay-Sachs disease, causes retardation only in persons who are homozygous; that is, only when both genes governing the characteristic are defective will the child be retarded. If a person affected by retardation caused by recessive genes marries a non-carrier, their children will be theterozygous; that is, they will carry the gene but not manifest the trait. In future generations, the gene may be lost (where no child of the carrier receives the deleterious gene, but instead the dominant, normal gene) or transmitted in a heterozygous state, or coupled with a matching recessive gene. Only in the last case will the descendant manifest the characteristics of retardation.

Thus, the child of a recessively retarded parent will be affected by the same form of retardation only if the other parent also carries the defective gene. If the other parent is heterozygous, there is a 50 percent chance that the child will be retarded. If the other parent is homozygous, the probability of retardation increases to centainty. On the other hand, two heterozygous parents, both of whom will appear normal, have a 25 percent chance of conceiving an affected child. ${ }^{67}$

By contrast, where retardation is attributable to a dominant gene, as in Downs syndrome, the risk of retardation in children of a retarded parent is 50 percent. Since the retarded parent carries at least one defective gene and since it is dominant, the gene and hence retardation will appear statistically in at least half the offspring. ${ }^{58}$

The significance of these percentages is plain. In cases of retardation due to recessive genes, the retardation of a prospective parent is only one factor in determining the risk of retarded offspring. The presence of a recessive gene in the other parent is necessary to

56. A. Deutsch, The Mentally Ill in America 374 (2d ed, 1949). Another author reported that 15 percent of retarded children at two institutions were born of parents one or both of whom were retarded; this means that 85 percent were born of "normal" parents. Gamble, What Proportion of Mental Deficiency Is Preventable by Sterilization?, 57 AM. J. MENTAL DeFIC. 123, 124 (1952).

57. See generally Vukowich, supra note 11, at 209-11.

58. Id. See notes 49-51 and accompanying text supra. 
create any risk of retardation in the children. Only where the defective gene is dominant can future retardation properly be presumed statistically.

Yet sterilization statutes aimed at reducing inherited retardation continue to apply to broad classes of retarded persons without regard to the dominant or recessive character of the defective gene or to the fact that only certain forms of retardation are genetic at all. Such legislation may be constitutionally defective for both under- and overinclusiveness.

Statutes authorizing sterilization only of the retarded may be under-inclusive because normal carriers far outnumber retarded carriers. A truly effective program of eugenics would require sterilization of all those who carry the defective gene, not just those who manifest its traits. ${ }^{59}$ As one author concluded: "It has been estimated that the carriers are froin 10 to 30 times more numerous than the affected persons. [A thorough program of eugenics] would involve the the sterilization of . . . at least $10 \%$ of the population."

Statutes that apply to all retarded persons may also be over-inclusive because some forms of retardation are not caused by defective genes. Moreover, only dominant genes pose a substantial risk of retardation if just one parent is a carrier. ${ }^{61}$ Hence, a statute premised on eugenics risks imvalidation for over-mclusiveness unless it limits sterilization to only those retarded persons who carry a dominant defective gene.

In addition, even a statute drawn with relative precision might be unconstitutional if it fails to provide less drastic alternatives in appropriate cases. For example, genetic counseling of the retarded and their spouses might reduce retardation attributable to recessive genes. Since both parents must carry the defective gene in order to produce retarded offpsring, a person affected by a recessive form of retardation can avoid the likelihood of retarded children by not marrying a person carrying the same defective gene. Similarly, for those types of retardation with dietary causes the state might test infants for the relevant genetic disability. ${ }^{62}$ If testing disclosed a risk of retardation, the child's diet could be controlled accordingly. Finally, in certain limited circumstances, temporary contraception might be appropriate where sterilization would not be. Although any form of imvoluntary contraception denies the individual the right to procreate, temporary contraception has the obvious advantage of reversibility. Hence it

59. See text accompanying note 51 supra.

60. Bligh, Sterilization and Mental Retardation, 51 A.B.A.J. 1059, 1062 (1965).

61. See generally T. DobZHANSKY, MaNKIND Evolving (1962).

62. See Cal. Health \& Safety Code $\$ 309$ (West Supp. 1974). 
might be appropriate for limited periods when the cause of retardation has yet to be ascertained.

\section{IV}

\section{FItNesS for ParenthoOd as a BASIS FOR STERILIZATION}

While the state has an obvious interest in ensuring that children receive sufficient care and attention to develop normally, fitness for parenthood remains difficult, if not impossible, to define with any specificity. Statutes that establish general standards of fitness for parenthood usually refer only to the physical, intellectual, and emotional development of the child; moreover, they are typically phrased in the negative, defining unfitness rather than fitness. ${ }^{.3}$ The presumption that retarded persons make unfit parents must therefore be evaluated in light of the imprecision used in legislative attempts to define fitness for parenthood for the population as a whole.

The relation of retardation to parental unfitness is far from clear. Although the standard definition of retardation-diminished measured intelligence coupled with impairment in adaptive behavior ${ }^{64}$-has a superficial sinplicity, it imcludes enormous variations in ability. Four levels of retardation are usually recognized: (1) mild, which includes persons who through special education can usually be brought to a state of self-sufficiency; (2) moderate, which encompasses those who can learn to function adequately in the home or in a sheltered working situation; (3) severe, which applies to persons who can learn self-care, but who have little or no potential for economic productivity; and (4) profound, which includes those who can at best learn basic self-care. ${ }^{05}$ Almost 90 percent of persons classified as retarded are in the first category, afflicted with only mild retardation. ${ }^{\text {Bo }}$

A prograin which would use IQ as a basis for determining fitness for parenthood inust take into account the imprecision of the testing process $^{67}$ and the fact that both functional ability and testing scores

63. For example, the Iowa code enumerates these indicia of unfitness: "debauchery, intoxication, habitual use of narcotic drugs, repeated lewd and lascivious behavior, or other conduct found by the court likely to be detrimental to the physical or mental health or morals of the child." IowA CODE ANN. $\$ 232.41$ (1969).

64. The American Association on Mental Deficiency has promolgated the following definition of mental retardation: "Mental Retardation refers to subaverage general intellectual functioning which originates during the developmental period and is associated with impairment in adaptive behavior." $\mathrm{H}$. ROBINSON \& N. RoBINSON, supra note 50, at 33-34.

65. National Association for Retarded Chitdren, facts on Mental ReTARDATION 4 (1971).

66. Id. at 15 .

67. As one authority has stated:

We now realize that to ineasure adequately the ability of an individual we have to test other phases of intelligence to supplement ... the Binet I.Q. 
can be improved through education and behavior modification. ${ }^{68}$ It must consider the possibility of cultural bias in the testing procedure. ${ }^{60}$ Moreover, the tests were designed only to measure suitability for placement in an educational program; any correlation to fitness for parenthood would be fortuitous.

There is, however, undoubtedly some relationship between intelligence and fitness for parenthood. For instance, a parent's ability to provide for a child's intellectual growth probably decreases with

We also realize that a single rating, with all the possibilities of accidental success or accidental failure, is not enough to determine the degree of ability along any one line. It is necessary to consider the total picture in order to make a reasonably reliable decision as to who is or who will be able to manage himself and his affairs with ordinary prudence, and in cases of inability to do so, to determine whether this inability is actually due to mental defect existing from birth, or from an early age, or due to some physical defect or lack of training.

Arthur, Pseudo-feeblemindedness, 52 AM. J. Mental Defic. 137, 138 (1947).

Of particular interest in this connection are studies such as one in which a 17year-old boy, microcephalic and severely retarded, was taught to read on an elementary level in just two years. Sidman, Reading and Auditory-Visual Equivalence, $14 \mathrm{~J}$. Speech \& Hearing Research 5 (1971). See also L. Ullmand \& L. Krasner, Case Studies in Behavior Modification 358 (1965).

The I.Q. score reflects only "an mdividual's abihity level at a given point in time, in relation to his age norms." A. Anastasi, Psychological Testing 211 (3d ed. 1968).

68. See, e.g., Sidman, supra note 67, at 5 (1971); Garber, supra note 55, at 85-86. One author has stated that I.Q. "is not fixed and unchanging; and it is amenable to modification by environmental interventions." A. ANASTASI, supra note 67, at 211. See also Brazinsky \& Brazinsky, The Mentally Retarded: Society's Hansels and Gretels, Psychology TODAY, Mar. 1974, at 18, 24 (expectations of negative or positive rewards for high performance can significantly affect tested I.Q. of retarded children); Dobzhansky, Differences Are Not Deficits, Psychology Today, Dec. 1973, at 97.

69. See, e.g., Larry P. v. Riles, Civil No. C-71-2270 (N.D. Cal., filed Nov. 22, 1971) (class action alleging that six black children who had been placed in special elementary education classes for the mentally retarded were "victims of a testing procedure which fails to recognize their unfamiliarity with the white middleclass cultural background and which ignores the learning experiences which they may have had in their homes"). Denial of defendants' motion to dismiss is reported at 343 F. Supp. 1306 (N.D. Cal. 1972). See also Ross, De Young, \& Cohen, Confrontation: Special Education Placement and the Law, 38 ExCEPTIONAL CHILDREN 5 (1971).

As the court in Hobson v. Hanson stated:

[U]sing standard aptitude tests is not simply a matter of technical inability to estimate innate learning capacities of disadvantaged children. ... [T]he false images test scores can project because of this disability will lead teachers-and principals, when they are involved in making the decision about proper track placement-into misjudging the capabilities of these children. The consequence is to create a substantial risk of underestimating and thus undereducating the disadvantaged child.

269 F. Supp. 401,488 (D.D.C. 1967)

[T] he disadvantaged child's handicaps-both environmental and psychological-are such that standard aptitude tests cannot serve as accurate measureinents of innate ability to learn. In Dr. Cline's opinion these tests are worthless. The evidence that this is so is persuasive.

Id. at 484 . 
decreasing IQ. ${ }^{70}$ The ability to provide for a child's physical care may be similarly impaired; a parent of severely diminished intelligence might not have the anticipation and awareness to provide a safe environment for the child. Diminished intelligence also might cause frustration when the retarded parent attempts to deal with a developing child, especially in the highly-charged atmosphere which often characterizes relationships between parents and teenagers.

These general correlations, however, cannot be pressed too far. Empirical studies have shown that persons with mild or moderate forms of retardation can fulfill the responsibilities of parenthood. ${ }^{71}$ If help were needed in particular situations, social agencies might be used to supplement and enrich the home environment so that children of retarded parents could enjoy normal intellectual development. ${ }^{72}$ Moreover, persons who are moderately or even severely retarded are often warm and affectionate, and can provide suitable environments for child-raising. ${ }^{73}$

It follows that a presumption of unfitness founded solely upon retardation is unwarranted.

Such a presumption may also violate due process. The Supreme Court held, in Stanley $v$. Illinois, ${ }^{74}$ that a state could not deny child custody to unmarried fathers through a conclusive presumption that they are unfit parents. Even assuming that most unmarried fathers

70. The "Milwaukee Project" survey data showed that the lower the mother's I.Q., the greater the probability of her offspring scoring low on intelligence tests. For example, a mother with an I.Q. below 67 was some 14 times more likely to have a child test below I.Q. 67 than a mother with an I.Q. of 100 or above. Garber, supra note 55, at 73. The author stated that the goal of the' project was "to determine whether the development of intellectual deficiency may be prevented (as opposed to cured or remedied) by displacing the presumed adverse or negative factors in the social environment of disadvantaged children who stand at risk of becoming retarded." Id. at 76. The phrase "becoming retarded" was used because the initial study showed that infants of low I.Q. mothers tested normal to about age two and then exhibited a markedly progressive decline in their measured I.Q. Id. at 78. The early intervention approach appeared successful. See id. at 82-86.

71. See, e.g., Bass, Outline of Workshop-Marriage and Parenthood, in SexunL RrgHTS, supra note 8, at 136-37; Mickelson, The Feebleminded Parent: A Study of 90 Family Cases, 51 Am. J. Mental Def. 644 (1974). See generally J. Mattinson, MARRIAGE AND MENTAL HANDICAP (1970).

72. See Garber, supra note 55.

73. For example, in In re Jeannie Q., 32 Cal. App. 3d 288, 107 Cal. Rptr. 646 (2d Dist. 1973), the court characterized a moderately retarded mother (I.Q. of 61) as "unfortunate, albeit loving." Id. at 299, $107 \mathrm{Cal}$. Rptr. at 654. The physician found the children "very personable and relatable . . . receiving 'some kind of warmth."" Id. at 293, $107 \mathrm{Cal}$. Rptr. at 649 . Recent studies have indicated that the capacity of retarded adults to relate and adapt has been underestimated. H. RoBinson \& $N$. Robinson, supra note 50, at 541-46. See also Abbott \& Ladd, . . Any Reason Why This Mentally Retarded Couple Should Not Be Joined Together . . , 8 MENT. RETARD. 45 (1970).

74. 405 U.S. 645 (1972). 
would be unsuitable and neglectful parents, said the Court, an individualized determination of unfitness is still necessary. ${ }^{75}$ The rearded person who is sterilized as a presumptively unfit parent faces, if anything, a more severe deprivation on equally unconvincing evidence.

But even if involuntary sterilization is permitted only after a finding of parental unfitness, it may still be unconstitutional if less restrictive alternatives are available. For example, adoptive placement might accommodate the interests of a retarded parent in having a child while protecting the child's welfare if the retarded parent proved to be unfit. In addition, since determinations of prospective parental fitness are imprecise, ${ }^{76}$ the state might defer decisions on sterilizations until a person has had an opportunity to function as a parent, and has failed. Determinations then would be based upon objective evidence, not conjecture. ${ }^{77}$ These alternatives may subject the retarded person to the trauna of termination of parental rights, and might pose significant risks for the first child of a retarded parent. Nonetheless, the difficulties surrounding prospective determination of parental unfitness at least warrant their consideration. Since lack of fitness for parenthood is a quality not wholly reserved to those of diminished intelligence, ${ }^{78}$ involuntary sterilization predicated on parental unfitness and limited to the retarded might also be constitutionally defective for under-inclusiveness. As discussed earlier, ${ }^{79}$ underinclusive classifications affecting fundamental interests have been held to violate the equal protection clause. A sterilization statute which did not extend the same treatment to all unfit parents, regardless of retardation, could be similarly challenged.

Thus, as was the case with eugenics, involuntary sterilization of retarded persons predicated on parental unfitness may be constitu-

75. Id. at 658 .

76. See notes $67-69$ and accompanying text supra.

77. Not only are the standards imprecise, but allowing the exercise of discretion exposes retarded persons to the prejudice of decision-makers who share the general bias against those of low intellect.

78. As one practitioner observed:

In my 20 years of psychiatric work with thousands of children and their parents, I have seen percentually at least as many "intelligent" adults unfit to rear their offspring as I have such "feeble-minded" adults. I have-and many others have-come to the conclusion that, to a large extent iudependent of the I.Q., fitness for parenthood is determined by emotional imvolvements and relationships.

Bligh, Sterilization and Mental Retardation, 51 A.B.A.J. 1059, 1062 (1965). See generally, Am. Humane Assoc., Chimdren's Div., National Symposium on Chind Abuse (1972); P. DeCourcy \& J. DeCourcy, A Silent Tragedy-Chmd Abuse IN the Community (1973); L. KanNer, A Mintature TeXtboor of Feeblemindedness (1949).

79. See notes 31-32 and accompanying text supra. 
tionally defective for both over-inclusiveness and under-inclusiveness. Lack of fitness for parenthood is not characteristic of all retarded persons, nor is this disability limifed only to the retarded. Only those statutes precisely drawn to avoid either pitfall can survive constitutional challenge.

\section{V \\ VOLUNTARY STERILIZATION OF THE RETARDED}

Beyond being subject to involuntary sterilization in many states, the retarded face special problems of voluntary sterilization. These problems may be summarized in two questions. When is consent voluntary? Who may give that consent? The issues raised by the first of these questions are covered thoroughly in another part of this Symposium, ${ }^{80}$ and therefore need not be discussed in detail here. It is enough to note that voluntary sterilization must be truly voluntary. It cannot be used as a condition to beneficial treatment, such as release froin an institution ${ }^{81}$ or receipt of welfare benefits. ${ }^{82}$

The second question raises more complex issues. Since a retarded person for whom sterilization is thought appropriate is often either a minor or a declared incompetent, ${ }^{83}$ parents or other legal surrogates frequently possess authority to consent for them. Our culture presumes that parents are interested in the best welfare of their children, and the theory behind appointing a guardian or conservator is that this person will represent the interests of the incompetent. In the sterilization context, however, parents or guardians often have interests that conflict with those of the retarded child. The parents of a retarded child may have understandable fears that the grandchild will also be retarded. Moreover, the parents may perceive a danger

80. See Wexler, Foreword-Mental Health Law and the Movement Toward Voluntary Treatment, 62 CAIIF. L. REv. 671 (1974) (this issue).

81. See The Mentally Disabled AND THE LAw, supra note 12, at 218; cf. Kaimowitz v. Mich. Dep't of Mental Health, Civ. No. 73-19434-AW (Wayne County, Mich., Cir. Ct., July 10, 1973), 5 Clearinghouse Rev. 302-03 (September, 1973). But see In re Sterilization of Cavitt, 182 Neb. 712, 721, 157 N.W.2d 171, 178 (1968).

82. See Relf v. Weinberger, 42 U.S.L.W. 2493 (D.D.C. Mar. 15, 1974), where the court held that consent is not voluntary if accepted under threat of cutoff from program benefits.

83. Mental retardation does not necessarily result in want of legal capacity. For example, the Indiana Probate Code defines an incompetent person as one who is incapable "by reason of insanity, mental illness, mental retardation, senility, habitual drunkenness, excessive use of drugs, old age, infirmity, or other incapacity, of managing his property or caring for himself or both. IND. STAT. ANN. 29-1-18-1(c)(2) (Burns Supp. 1973). The Indiana code also states that a contract is void when "executcd by anyone previously adjudged to be an incompetent." IND. STAT. ANN. 29-1-18-41 (Burns 1972) (emphasis added). See also The Mentally Disabled and the LAW, supra note 12 , at $250-65$. 
of their retarded child proving to be an unfit parent, and might wish to avoid the risk of shouldering the responsibilities of grandchildreneither normal or retarded-in that event. ${ }^{84}$

Alternatively, the surrogate's consent might be motivated by the overprotectiveness that so often characterizes parents of the retarded.85 Where these or other similar motivations prevail, it is doubtful that the surrogate's decision to allow sterilization serves the best interests of the retarded person. Thus, the legal effect of such consent is coinpromised.

The inost direct way to avoid such possible conflicts of interest is simply to allow the retarded person to decide himself whether or not to be sterilized. Retardation is not co-extensive with lack of capacity to give inforined consent. Most mentally retarded persons can appreciate the responsibilities of parenthood and the implications of sterilization. This is certainly true of the 90 percent who suffer from mild retardation..$^{86}$ Likewise, many considered to be moderately retarded might also be capable of informed consent. ${ }^{87}$ Those who proved to be of doubtful competence could perhaps be assisted in their decision by professional counseling, provided it was strictly limited to noncoercive advice. ${ }^{88}$

While there is undoubtedly some point at which diminished intelligence prevents informed consent, such cases are far from com-

84. For example, one mother asserted that she has the right to rear her son in any manner she sees fit so long as she violates no law in the process, to prevent her son froin fathering mentally deficient children who will become her dependents, and to avoid financial responsibility for any of her son's children. See Brief for plaintiff supporting motion to correct errors at 2-3, A.L. v. G.R.H., No. 72-CIV-2597 (Super. Ct. of Vanderburgh County, Ind., filed Sept. 13, 1973). Cf. B. Farber, Mental Retardation-ITs Social CoNTEXT aNd Social CoNSEQuences 152 et seq. (1968); Perske, supra note 8, at 49-50; Grossman, Brothers and Sisters of Retarded Children, Psychology TODAY, April 1972, at 82.

85. Courts are often equally protective. In justifying its decision to uphold the sterit.7ation of a woman with several children, the Nebraska Supreme Court stated:

Cunsideration was given to the probable effect upon her of having more children. her minimal capacity to handle the responsibilities of parenthood, the possibility of producing mentally defective children, and the probability that added responsibilities of parenthood would in all likelihood handicap her potential rehabilitation.

In re Sterilization of Cavitt, 182 Neb. 712, 717, 157 N.W.2d 171, 176 (1968).

For a contrary viewpoint, where the author takes the position that retarded persons must have the right to take risks and to come to grips with the decision whether or not to become a parent, see, e.g., PERSKE, supra note 8, at 36-38, 43-44.

86. See note 65 supra.

87. See note 89 infra.

88. As one author has observed, where conflicts arise between agencies and clients it is not unusual for the agency to prefer its interests-for example, in preventing future service needs-over the best interests of individual clients. CrTIZEN ADVOCACY ANd PRotective SeRvices for the IMPamed aNd Handicapped 10-11 (W. Wolfensberger \& H. Zauha eds. 1973). 
mon. ${ }^{89}$ Moreover, many retarded persons in this quite limited group are incapable of reproduction, because of physical or genetic disabilities, and others remain in protected environments which make sterilization unnecessary. In short, the state may rarely confront a retarded individual who should be sterilized, but who lacks the capacity to consent.

Thus, at least in many instances, the law-rather than extending the scope of involuntary sterilization-should maximize personal choice and recognize the capability of most retarded persons to make the decision whether or not to be sterilized. The role of legislation should be to provide procedural safeguards to ensure the voluntariness of the choice rather than eliminate the role of free choice.

\section{CONCLUSTON}

The stereotype of a retarded person is that of a person incapable of self-care, who is sexually active, and who will pass his or her degeneracy to any offspring. There is, however, a wide range of capability among those who are labeled retarded, including both the ability to parent and the ability to decide not to become a parent. In addition, studies have shown that the sexual activity among retarded persons is quite likely less than that among other elements of the population. And finally, genetic defects are only one source of retardation, and even retardation which is genetically caused is not necessarily inherited by the children of the person affected. The stereotype, in short, is far from accurate.

The right to procreate is fundamental. Any program which would irrevocably frustrate this right is therefore constitutionally suspect and must be based upon empirically verifiable data, not preju-

89. As one authority in the field stated:

[T] retardates who are able to live in the community can understand the operation, and often reqnest it. The Human Betterment Association of America, whose program is devoted to research, education, and service in the field of voluntary sterilization, has had a similar experience.

Bass, Marriage, Parenthood and Prevention of Pregnancy, 68 AM. J. Mental Defic. 318 (1963).

A chaplain at a school for the retarded agreed that many retarded persons understand the nature of sterilization, believing that "even an individnal with an I.Q. of 38 can be helped to understand the meaning of sterilization." Bass, supra note 71, at 133. Also reported is the statement of a youmg woman with an I.Q. of less than 50 who told a social worker: "I am a mongoloid. You know it's not good. I shouldn't have a baby. I want birth control." Id.

It should be noted that of the estimated 6 million retarded persons in our population, approximately 5.4 million are in the mildly retarded range, about 366,000 in the moderately retarded range, 214,000 in the severely retarded range, and 92,000 in the profoundly retarded range. Thus, over 90 percent of retarded persons have an I.Q. of 52-55 or above. See Facts on MENTAL RETARDation, supra note 65, at 15. 
dice nor conjecture. Moreover, it must encompass both procedural and substantive standards to ensure against unwarranted intrusion upon the dignity of the individual person, retarded or not. Neither Buck $v$. $B e l^{20}$ nor the present day statutes supposedly shielded by that decision can withstand critical examination today.

90. 274 U.S. 200 (1927). 